О. М. Санівський,

кандидат педагогічних наук, старший викладач (Уманський державний педагогічний університет імені Павла Тичини) san4elo45800@ukr. net

ORCID: 0000-0002-9312-9369

\title{
ФІЛОСОФІЯ ДЛЯ ДІТЕЙ У ПЕДАГОГІЧНІЙ СПАДЩИНІ В. СУХОМЛИНСЬКОГО
}

У статті на основі комплексного аналізу науково-педагогічної спадщини з'ясовувалася сутність філософськоӥ системи В. Сухомлинського для дітей. Педагогічна спадщчна вивчалася на ментальному, філософському, історичному, педагогічному, синергетичному рівнях. У результаті дослідження дійшли висновку про необхідність введення Сухомлиністики як окремої навчальної дисципліни у кожному педагогічному університеті Украӥни, надавщи їй відцентрового змісту у підготовиі вчителя-патріота, національно свідомого громадянина, інтелектуала XXI століття, украӥнознавия планетарного мислення.

Ключові слова: В. Сухомлинський, філософська система В. Сухомлинського для дітей, педагогічна система В. Сухомлинського, формування украӥния планетарного мислення.

Постановка проблеми. У постанові Кабінету Міністрів України від 3 листопада 1993 року № 896 "Про державну національну програму "Освіта" ("Україна ХХІ століття")" наголошується на необхідності формування гуманітарного мислення, опанування рідною, державною мовою, прилучення молоді до літератури, музики, образотворчого мистецтва, надбань народної творчості, здобутків української і світової культури, відображення у змісті історичної освіти закономірностей історичного розвитку, широкого вивчення україно- (народо-)знавства, етнічної історії та етногенезу українців.

У національній доктрині розвитку освіти України у XXI столітті йдеться про те, що освіта України грунтується на культурно-історичних цінностях українського народу, його традиціях і духовності. Вона розвивається на основі педагогічної спадщини Київської Русі, доби українського козацтва, світоглядної парадигми Володимира Мономаха, Петра Могили, Г. Сковороди, Т. Шевченка, І. Франка, Я. Чепіги, С. Русової, Г. Ващенка В. Сухомлинського та інших видатних мислителів.

Саме педагогічна спадщина Василя Олександровича Сухомлинського у прокрустовому ложі тоталітарного режиму утверджувала і зміцнювала в освіті нашу ментальність, національну ідею, духовні і моральні цінності українців, у той же час сприяла оволодінню багатствами світової культури, виховувала повагу до інших народів, мала гуманістичний характер.

Осягнути педагогіку В. Сухомлинського у контексті запитів освіти XXI століття - це важливе завдання державної ваги. Ми знаємо, що "спадщина Сухомлинського наділена здатністю оновлюватися в часі, набувати загостреної актуальності, а 3 іншого боку - вона немов ланцюгом пов'язана по руках $\mathrm{i}$ ногах комуністичною риторикою, що надає їй, на перший погляд, майже безнадійної анахронічності" [3].

Аналіз основних досліджень і публікацій із зазначеної проблеми. Г. Клочек наполягає на осмисленні педагогічного доробку Василя Олександровича: "Ми не такі багаті, щоб легковажити спадщиною, напрацьованою кров'ю та потом попередніх поколінь, яким випало жити у смутні часи" [3]. Він першим висловив думку про необхідність серйозної уваги дослідників до проблеми українськості педагогічної спадщини В. Сухомлинського.

На думку М. Жулинського, Україна сьогодні виявилася не захищеною духовною оболонкою національної ідентичності, всім комплексом національних цінностей і пріоритетів, Україна повинна вийти на шлях гуманістичного розвитку, що передбачає важливість розглядати людину як головний pecypc [4: 5-10].

Учені, що досліджують проблеми української ментальності, стверджують, що глибинну українськість визначає така якість, як залюбленість у рідну природу. На думку Б. Липинського, наша земля, земля предків, має свою унікальну енергетику, яка суттєвим чином впливає на долю нашого етносу, на його ментальність. Д. Чижевський писав, що велику роль у формуванні світосприймання українського народу відіграла природа України. Життя українців у неймовірно сприятливих природно-кліматичних умовах серед барвистих краєвидів степів, ланів і лісів спонукало до розвинення споглядальності, чуттєвості та сердечності, самозаглибленості у власні почуття. Занурення у цей дивовижний світ, щоденне спілкування з природним середовищем не могли не відбитися на душі народу. Це добре розумів В. Сухомлинський. Він "прагнув того, щоб усі роки дитинства навколишній світ, природа постійно живили свідомість учнів яскравими образами, картинами, сприйняттями й уявленнями, щоб закони мислення діти усвідомлювали як струнку споруду, архітектура якої підказана ще стрункішою спорудою 
- природою. Щоб не перетворити дитину на сховище знань, іiі свідомість у комору істин, правил і формул, треба вчити її думати. Сама природа дитячої свідомості й дитячої пам'яті потребує, щоб перед малюком ні на хвилину не закривався яскравий навколишній світ з його закономірностями ... Гострота дитячої пам'яті, яскравість думки зі вступом до школи не тільки не послабляться, а й ще подужчають, якщо середовищем, у якому дитина буде вчитися мислити, запам'ятовувати і міркувати, стане навколишній світ" [3: 226].

Окреслення невирішених питань, порушених у статті. Не дивлячись на наявність результатів досліджень багатьох учених із даної проблеми, вона досліджена недостатньо. Узагальнення потребують різнобічні дослідження педагогічних ідей та досвіду В.Сухомлинського, які становлять педагогіку школи майбутнього, закорінену в українську ментальність.

Формулювання мети і завдань статті. На основі комплексного аналізу науково-педагогічної спадщини з'ясувати сутність філософської системи В.Сухомлинського для дітей. Дана мета буде досягнута за умови суть педагогіки В. Сухомлинського як педагогіки школи майбутнього в контексті запитів освіти XXI століття на ментальному, філософському, історичному, педагогічному, синергетичному рівнях.

Виклад основного матеріалу з обгрунтуванням отриманих наукових результатів. Запроваджені Василем Сухомлинським уроки на лоні природи є унікальним явищем в історії світової педагогіки. Він писав: "Якщо ж ізолювати дітей від природи, якщо 3 перших днів навчання дитина сприймає тільки слово, то клітини мозку швидко стомлюються і не справляються з роботою, яку пропонує вчитель. А цим клітинам треба розвиватися, міцніти, набиратися сили. Ось де причина того явища, 3 яким багато вчителів часто зустрічаються в початкових класах: дитина тихо сидить, дивиться тобі в очі, ніби уважно слухає, але не розуміє ані слова, бо педагог усе розповідає і розповідає, тому що треба думати над правилами, розв'язувати задачі, приклади - це все абстракції, узагальнення, немає живих образів, мозок стомлюється ... Тут і народжується відставання. Ось чому треба розвивати мислення дітей, зміцнювати розумові сили дитини серед природи - це вимога природних закономірностей розвитку дитячого організму. Ось чому кожна подорож у природу є уроком мислення, уроком розвитку розуму" [3: 81-82].

Ці роздуми Василя Олександровича є особливо актуальними у наш час, коли переважна більшість дітей живе в урбанізованому просторі, в міських джунглях, де по суті немає краси природи, як-от: росяних світанків, широких квітучих луків, зелених гаїв, серпневих зорепадів. Деякі вчені б'ють тривогу i застерігають, що сучасне міське середовище $\epsilon$ згубним для дитячого організму, руйнує психічне $\mathrm{i}$ фізичне здоров'я дитини. У сільських дітей Павлиської школи виховний простір не обмежувався стінами школи, він продовжувався в полі, на кургані, на луках, у саду, серед квітів, дерев, а у сучасної міської дитини він обмежений "євроремонтованими" стінами школи, квартири, стандартними "євровікнами", "євродверима", "євромеблями". Все уніфіковано, стандартизовано, алгоритмізовано. І це проблема, яку доведеться вирішувати освітянам XXI ст.

Свою школу Василь Олександрович називав "Школою радості". I це знаково у сьогоденні, оскільки сучасна людина все більше дистанціюється від емоцій, особливо позитивних. Засоби масової інформації все більше продукують негатив, сіють відчуття жаху, зневіри, безнадії, суму. Таким чином формується колективний егрегор страху, що згубно впливає на здоров'я, психіку людини, зміцнює в людині рабську покору, паніку. На такому фоні вражає статистика дитячих суїцидів, наркоманії, пияцтва, проституції, роздратування серед дітей. Про шкоду негативних емоцій, про їх згубний вплив писали філософи, соціологи, педагоги, психологи, езотерики, зокрема О. Клізовський: "Безсумнівно, подих, просякнутий злом, буде шкідливим, якщо отрута відкладається в організмі у процесі роздратування, якщо слина може бути отруйною, то й дихання може бути отрутоносним. Необхідно побачити, скільки злоби видихається, яке різноманіття зла може стати компонентами нової отрути за умов великого скупчення людей... Настав час потурбуватися про чистоту нашого задвір'я. Чистота необхідна і на подвір’ї, і в людському диханні. I перше, що видихають роздратовані люди, це той же бруд, той же покидьок ганебний. Необхідно проштовхнути в людську свідомість, що кожен покидьок може заразити близьких. Покидьок морального розтління гірше будь-яких вивержень" [4: 574].

В унісон цим думкам звучить вислів сучасного філософа, соціолога Даріо Саласа Соммера: "Людина, що відчуває інтенсивні почуття, випромінює тваринний магнетизм. Ненависть - руйнівне почуття, отож магнетизм набуває руйнівного імпульсу... Наміри, почуття і пристрасті роблять біомагнетизм людини позитивним чи негативним. Це не метафізика, а звичайне явище, таке, як збереження інформації на жорсткому диску комп'ютера. Той, хто ненавидить, накопичує руйнівні вібрації в особистому магнетизмі и в L-fields, проектуючи негативну енергію на все, що ненавидить.

Ненависть, що накопичилася, шкодить, перш за все, самій людині, оскільки це руйнівне і негативне почуття вносить безлад, розпорошує і забруднює L-fields, руйнуючи здоров'я. Багато тяжких хвороб є наслідком ненависті, що переповнює людину. Образа, ненависть, заздрість і жага руйнування становлять деструктивні, дисгармонійні ноти випромінювання нашої психіки, які діють як агенти смерті в клітинах тіла. Руйнівний вплив негативних емоцій уже визнано медициною, і вчені згодні з тим, що всі хвороби 
залежать від психосоматичного фактора. Наприклад, було помічено, що відновлення після операції у радісних і гармонійних людей у люблячій родині відбувається набагато швидше, ніж в одиноких, переповнених гіркоти і ненависті" [5: 364].

Психосоматичний фактор, як наукова проблема, порушується і активізується вченими різного фаху на початку XXI століття, однак В. Сухомлинський осмислив іiі у своїй "Школі радості" ще в середині XX століття. Радість - одне 3 ключових понять його педагогіки: "Навчити відчувати - це найважче, що $\epsilon$ у вихованні. Школа сердечності, чуйності, щирості, співчутливості - це дружба, товариство, братство. Дитина відчуває найтонші переживання іншої людини тоді, коли вона робить щось для щастя, радості, душевного спокою інших. Любов маленької дитини до матері, батька, бабусі, дідуся, якщо вона не одухотворена творенням добра, обертається на егоїстичне почуття: дитина любить маму, наскільки мама $\epsilon$ джерелом радощів, потрібна ій для радощів" [3: 167-168]. Отже, вчений осмислює по-філософськи концепт "радість" і продовжує: "А треба виховувати в дитячому серці справді людську любов - тривогу, хвилювання, турботу, переживання за долю іншої людини. Справжня любов народжується тільки в серці, що пережило турботу про долю іншої людини" [3: 168].

Серце В. Сухомлинського переймалося проблемами планетарними. Він зарекомендував себе не тільки як учений-педагог, а як і еколог, економіст, філософ, психолог, літератор, історик, мовознавець, етнолог, соціолог, у педагогіку він інтегрував різні сфери людського знання, що відповідає міждисциплінарній науці синергетиці, проблеми якої було вперше включено до плану фундаментальних та прикладних досліджень Інституту психології імені Г. С. Костюка АПН України. Уже в ХХІ столітті В. Кремень дослідив, що крізь призму синергетики освіта перетворює 3 можливості в дійсність формування творчої, високоінтелектуальної особистості, здатної орієнтуватися у колосальних потоках інформації, вільно існувати у відкритій, складній системі відносин людини та сучасної цивілізації [6].

За часів В. Сухомлинського населення підрадянської України жило скромно й задовольнялося малим. Звісно, у цієї скромності була своя норма, але й був сильний мотив приниження. Після воєнного лихоліття, голоду, обмежень у всьому, повної аскези, злиднів, відбудови народного господарства люди все-таки стали жити краще. Батьки намагалися все зробити для того, аби життя їхніх дітей було ситим, заможним. Люди все більше намагалися задовольнити матеріальні потреби дітей. I задоволення матеріальних потреб поступово починає превалювати над потребами духовними. Цю тенденцію ще у 50$\mathrm{x}$ роках $\mathrm{XX}$ століття помітив В. Сухомлинський. Його турбувало, що "... чим більше радощів життя дається молодому поколінню, тим з більшою турботою повинні ми вкладати в юні серця ті моральні цінності й багатства, ті святині, без яких життя може перетворитися в бездумне проїдання створеного старшими поколіннями, в "існування, - за словами Ф. Достоєвського, - для власної пельки" [7: 311].

За останні десятиліття суспільство змінилося кардинально, бажання досягти задоволення своїх потреб досягли апогею. Такі "танталові муки" призводять до катастрофи, коли людина потопає у бруді власного сміття у прямому і переносному значенні. Василь Олександрович намагався знайти такий ключик, який би прокрутився у психіці людини, аби вона намагалася прийти до усвідомленого, раціонального споживання; переймався проблемою формування у своїх вихованців культури потреб. Він наводить наступний приклад: "В одній школі-інтернаті сталося таке. Тридцять семикласників пішли в неділю 3 вихователем до лісу. Був квітень, з вечора йшов дощ, учні взули калоші. А вдень випогодилося, сонце підсушило землю, калоші стали важкими, і підлітки викинули їх в яр, ще й землею присипали. Зробили так, щоб і вихователь не бачив. Коли потім у них запитали: "Навіщо ви це зробили?", вони відповіли: "Все одно скоро видадуть нові...". Не варто розповідати, чим закінчилася уся історія. Закінчити іiі якимось одним "виховним заходом" неможливо. Завершення іiі впирається в ту саму проблему становлення громадянина" [7: 310].

Проблема задоволення потреб стає ще гострішою у наш час. Якби поради великого педагога, його рецепти "культури потреб" активно застосовувалися в школі всі роки незалежності, якби вони стали дороговказом не тільки для освітян, а надто для державотворців, то сьогодні ми не мали б трагедії на Львівському сміттєзвалищі, не мучилися би у "танталових муках достатку". В Україні надто гостро стоїть проблема обмеження споживання, формування у населення раціональної культури потреб. Вектор цінності від років "перебудови" впродовж років незалежності змінився таким чином, що жити скромно стало ганьбою, адже багатство оголосили мірилом успіхів та гідності і відпустили повіддя приватизації. І тепер ті, хто піднявся рівнем доходів вище на сходинку-другу, дивляться вниз з осудом: "Мало маєш отже, погано працюєш. А чи не хочеш наплодити дітей і повісити мені, чесному платнику податків" (читай злодію і крадію). Таким чином, психологія багатої людини не дозволяє їй прийняти тезу про скромність, філософію самообмежень, добровільну бідність.

Натомість у західному світі не годиться демонструвати свою заможність, рекламувати статки, оскільки це суперечить європейській етиці, тут відбувається рух у бік обмеження споживання. Так, в англійській мові з'явилося слово oregonizm (орегонізм), навіяне психологією жителів штату Орегон. Орегонізм розуміють як прагнення до способу життя, який більшою мірою підтримує гармонію між людиною та навколишнім середовищем. Орегоністи орієнтовані на задоволення реальних потреб, 
заплющуючи очі на те, що вважається престижним у споживацькому суспільстві. В Україні повинна ще виникнути культура споживання, сформуватися культура потреб, що дасть вивільнити творчий потенціал особистості. Сам В. Сухомлинський був зразком скромної людини, з високими моральними якостями, тому не тільки його педагогічний досвід, але і його особистість може бути орієнтиром у формуванні культури споживань сучасних українців. Актуальними сьогодні $є$ його думки про найважливішу ділянку спільної роботи сім'ї та школи: "Мабуть, вирішальним у вихованні бажань є обмеження, заборона. В дитячі і отрочі роки вихованець повинен, і не раз, переконатися на досвіді в тому, що є таке серйозне слово "не можна". Ми прагнемо до того, щоб діти співвідносили свої бажання 3 можливостями батьків. Скромність примушує підлітка, юнака, дівчину відмовитися від тих матеріальних і духовних благ, які готові надати їм батьки, нерідко відмовляючи собі в найнеобхіднішому. Виховання скромності - одне 3 найважливіших завдань у системі морального виховання. Скромність не можна формувати в людини ізольовано від інших якостей. Скромність, помірність доступні лише тому, для кого праця стала виявом особистості, сферою духовного життя. Відчути аморальність примхи маленька людина може тільки за тієї умови, що їі почуття власної гідності розвивалися на основі праці, яка створює радість для інших людей. Той, хто нічого не дає людям, не знає впину своїм бажанням. А той, хто працює охоче і свідомо, звичайно, вміє стримувати свої бажання і вимоги, він ставиться до життя не по-споживацькому, йому вже можна довірити визначення міри благ для себе" [7: 327].

Філософія гедонізму, культ задоволення нині панує у світі: кіно, телебачення, Інтернет, реклами - все працює на те, аби спокусити юних жити винятково заради задоволення своїх бажань. Віртуальний світ все більше поглинає час, здоров'я, інтелект молодих людей, які таким чином дистанціюються від родини, книги, у них змінюється вектор цінностей, деформуються моделі поведінки, втрачається здоровий глузд. Раніше йшлося про чотири культи, сформовані В. Сухомлинським, - культ Батьківщини, культ матері, культ рідного слова і останній - культ книги. Якщо в молодої людини вихована пристрасть до читання, вона у вільний час не нудьгує від безділля і не шукає дешевих розваг і задоволень. Не хтось повинен задовольняти потреби людини, а вона сама повинна бути творцем свого духовного життя. Натомість сьогодні спостерігаємо, як ціла глобальна індустрія працює на те, щоб виховати людину-споживача, егоїста, прагматика. В освіті все більше скорочується гуманітарний простір. Учені-патріоти б'ють на сполох, що "теперішній стан викладання словесності в школі є явно кризовим. 3 цієї ситуації треба виходити будь-що. Інакше, коли зусиль, спрямованих на вихід із цієї кризи, буде недостатньо і вони виявляться згасаючими, це засвідчить, що процес духовної деградації суспільства став невідворотнім. Художнє слово для української цивілізації було однією 3 опорних конструкцій. Недарма ж антиукраїнські сили не раз розпочинали акції з дискредитації у свідомості сучасного обивателя таких імен, як Тарас Шевченко, Іван Франко, Леся Українка ... То були наміри піддати конструкції поступовій корозії" [8: 14].

Дистанціювання сучасної молоді від читання книг, власне занепад культури читання, вигідно неолібералам, які ні на дух не переносять нічого національного. "Після здобуття Україною незалежності якість мовно-літературної освіти почала знижуватися спочатку ледь помітно, а згодом - катастрофічно", - пише Г. Клочек [8: 14]. Річ у тому, що саме література має потужний націєтворчий потенціал, до того ж вона виконує історіознавчу, людинознавчу функції, тобто виховує людину-патріота, національно свідомого громадянина, на якого не чекають і якого не люблять ні пихата Росія, ні сита Європа. Завдання освіти XXI століття в Україні - повернути літературі величну роль "Королеви мистецтв", провідної гуманітарної дисципліни, що містить значний націєтворчий потенціал. Серед низки цінностей українського народу Книга посідала чільне місце. Ми віримо Слову, поклоняємося йому, воно для нас було Богом. Таке животрепетне ставлення до рідного Слова несе нам учення В. Сухомлинського: "Слово - це найтонший різець, здатний доторкнутися до найніжнішої рисочки людського характеру. Вміти користуватися ним - велике мистецтво. Тож оволодіймо цим різцем так, щоб з-під ваших рук виходила тільки краса" [7: 167].

Окрім морального здоров'я, Василь Олександрович дбав про фізичне здоров'я своїх вихованців. Він вважав, що поєднання здорового харчування, сонця, повітря, води, доступної по силі праці та відпочинку - це все стало цілющим і нічим не замінним джерелом здоров'я. Великий Учитель особливої ваги надавав оздоровчій силі природи, мислив масштабно в унісон таким титанам думки, як Б. Болотов, О. Клізовський, В. Липинський, С. Подолинський, М. Реріх, М. Руденко, Г. Сковорода, П. Сорокін, Д. Чижевський. Так, наприклад, лікарі вважають, що Сонце є основним джерелом постачання енергії серцю, м'язам і всім іншим органам людини і тварини. Все, що живе на Землі, безпосередньо підключене до цього джерела. Його енергія величезна, але біологічні істоти споживають ії в мізерних дозах, цілком достатніх для життя. Таким чином, наше Сонце, пульсуючи з частотою в один період на секунду, створює на Землі пульсації сердець усіх людей на суходолі і на морі. До цього випромінювання пристосовані й усі інші клітини тваринного і рослинного походження.

Саме Сонце як джерело здоров'я згадується в працях Василя Олександровича десятки разів, як-от: "Ми зустрічаємо сонце на кургані", "Зустрівши сонце, діти відчиняли двері з коридору до теплиці та 
входили у світ квітів", "Казка про Сонечко збагатилася новими образами", "Ми знову зустрічаємо сонце", "Тихого зимового ранку діти милувалися світанками", "Особливо, коли яскраво світило сонце, ми проводили цілі дні на повітрі". У розділі I "Школа радості" у книзі "Серце віддаю дітям" йдеться про те, що "Жайворонок - дитя сонця. В казці йдеться про те, що "народилася ця пташка з сонячного вогню". Тому наш народ і назвав іiі жайворонком - жар - ворон". Тобто В. Сухомлинський з раннього дитинства формував у дітей український світогляд, за яким Сонце - джерело усіх благ, йому наші пращури поклонялися, тому й називали нас у минулому сонцепоклонниками. За словами О. Чижевського, "важко погодитися 3 думкою, що народам, які колись жили, не вдалося додуматися до реальних уявлень про благотворну силу Сонця, яке створює життя на Землі, що незліченні міфи - це лише наївні казки. Вони підсумок багатовікового колективного досвіду, результат праці допитливих, невтомних поколінь, а часом і геніальних спостерігачів природи, імена яких майже втрачені" [9: 71]. Таким чином, українська стародавня філософія, яка володіла глибокою діалектикою, була перероблена на міфи. Її було перероблено для того, щоб навіть неписьменна людина усвідомлювала, якій силі природи присвятити своє життя [9: 71]. Згідно з дослідженнями сучасних учених, людина, яка живе за сонячним ритмом, космічним ритмом, може сподіватися на міцне здоров'я, якщо ж вона випадає 3 цього ритму, то починаються хвороби. Космічний / сонячний ритм 365 - 366 днів, космічний ритм людини - 36,5, що $\epsilon$ свідченням органічної залежності людини від Сонця. Японський дослідник Макі Таката у своєму листі до О. Чижевського писав: "Немає сумнівів, що сонячна радіація містить новий компонент, який характеризується сильною проникаючою спроможністю і сильним іонізуючим впливом на людське тіло, тобто вираженим біологічним ефектом ... Людина по суті являє собою живий сонячний годинник" [9: 67].

Великий філософ, письменник, герой України М. Руденко переконував: "А земне життя належить не Землі - кожною своєю клітиною, кожним ударом пульсу воно підпорядковане творчій діяльності Сонця, отже, відповідальність перед життям, по суті є відповідальністю перед Сонцем ... Ми чомусь не усвідомлюємо, що сонячне незмірно цінніше за земне ..." [9: 66].

В. Вернадський вважав, що люди є трансформаторами сонячної енергії, яку вони перетворюють у гримнотливі поїзди та літаки, у величезні потужності наших знавців, саме Сонцем докорінно перероблене і змінене обличчя землі. Отже, Сонце, на його думку, - це ми самі, наш мозок і наші руки.

Інтелектуалу В. Сухомлинському добре були відомі праці і В. Вернадського, і Г. Сковороди, i Д. Чижевського, і багатьох-багатьох інших мислителів. Їхня мудрість акумулювалася у його педагогічній теорії і практиці, яка є актуальною у контексті запитів освіти України у XXI столітті.

Василь Сухомлинський писав: "Глибокий слід у свідомості й емоційній пам'яті дітей залишаються "мандри", присвячені читанню однією з найбільш зворушливих сторінок "Книги природи" - "Сонце джерело життя". Спекотної літньої днини ми йдемо в поле, до садка, на виноградник. Перед нами - лани пшениці й соняшнику, грона винограду, жовтаві груші, майже достиглі помідори. В цих дарах родючості діти бачать сонячне світло і тепло. Усе, що треба людині, земля дає завдяки сонцю. Цей висновок, зроблений шляхом численних спостережень, порівнянь, установлення причинно-наслідкових зв'язків, викликає у малюків здивування, яке дає новий поштовх до лету думки. Діти вдивляються в навколишній світ, замислюються над походженням кожної речі. І почуття подиву ще більше поглиблюються, коли вони переконуються, що сонце - єдине джерело життя" [3: 244].

Як учений-мислитель, В. Сухомлинський розумів, що людина - істота не тільки космічна, але й земна, тому у своїй оздоровчій системі використовував також силу земної енергії. За словами М. Руденка, "людина - Живе Світло, руки Сонця і мозок його. Ці органи, як і весь ऑї організм, сформовані з сонячного світла за допомогою гравітації" [9: 71]. В. Сухомлинський звертається до своїх підопічних: "Так, дітки, ми йдемо до школи. Наша школа буде під блакитним небом, на зеленій травиці, під гіллястою грушею, на винограднику, на зеленому лузі. Знімімо тут черевички і ходімо босоніж, як ви звикли ходити раніше. - Діти радісно защебетали; їм незвично, навіть незручно ходити у спекотну погоду в черевиках. - А завтра приходьте босоніж, у нашій школі це буде найкраще" [3: 75]. У другому розділі "Роки дитинства" учений пише: "Усе літо діти ходили босоніж, не боялися дощу. В цьому я бачив особливо важливий засіб фізичного гарту... Медичною наукою доведено, що багато різновидів нежитю це не інфекційне захворювання, а реакція чутливого організму на різні зміни в довкіллі. Багаторічний досвід підказав: особливо чутливими є ноги. Якщо ноги бояться найменшого охолодження, людина піддається неінфекційному нежитю. Система зміцнення організму, яка склалася в нашій виховній роботі, починається із загартування ніг ... Якщо дитина не ходить в літню пору босоніж - ніяке купання та обтирання мокрим рушником не допоможуть" [3: 198-199].

Ці методи оздоровлення дітей сьогодні є особливо актуальними, оскільки сучасні діти ізольовані від землі взуттям, лінолеумом, євроремонтом, надлишок космічної енергії і нестача земної порушує електроліз в організмі людини, спричиняє низку хвороб. А життя в мегаполісах, міських джунглях, на поверхах ще більше дистанціює людину від землі. До того ж, за свідченням дослідників, сама планета 
Земля у XXI столітті випромінює нові вібрації, вона $є$ живою істотою, мислячою, є кристалом з багатьма виходами - енергетичними вершинами.

У світлі нових знань однією 3 найважливіших проблем є здоров'я людини. Покоління XXI століття пристосоване до нових вібрацій нашої планети, у них від народження закладені позитивні зміни в організмі й свідомості. У роботі вчителів 3 такими дітьми саме педагогічна спадщина В. Сухомлинського, його "педагогіка серця" стане в нагоді.

Сама "педагогіка серця" великого Учителя вимагає переосмислення і пристосування до реалій освіти України XXI століття, оскільки в останні роки відбулися незворотні зміни у суспільному, економічному житті, переорієнтовано вектор традиційних цінностей, зазнала деструкцій традиційна мораль. Першопричина сучасної кризи, за словами В. Вернадського, "одвічний конфлікт матеріального і духовного в людині". Саме матеріальне тисне на духовне у нашому суспільстві, і це позначається на освіті.

Якщо педагогіка В. Сухомлинського пропонує нам виховну модель, зорієнтовану на формування людини-творця, то сучасні реалії нав'язують нам необхідність "ліпити" усіма можливими і неможливими засобами людину-споживача.

Сучасним освітянам необхідно навчитися протистояти космополітичній системі стандартів, уніфікацій, знеособлення, слід сформувати національну систему цінностей і пріоритетів, забезпечену культурою традицій, моральною духовністю, усвідомленим патріотизмом, вірою в унікальність власного цивілізаційного образу та призначення. Така національна система освітніх цінностей представлена у педагогічній спадщині В. Сухомлинського, i саме вона відповідає запитам сьогодення i нашій українській ментальності. Як учитель і вихователь, він прагнув того, щоб закласти в юні серця моральні цінності, "створені й завойовані людством протягом багатьох століть - любов до Батьківщини і до волі, непримиренність до гноблення й поневолення людини людиною, готовність віддати свої сили й життя в ім’я найвищих ідеалів - щастя, свободи людей" [7: 414]. Все, що людині дороге, має бути у неї в серці. Вчений пише: "По-справжньому любити - це віддавати, творити, вкладати духовні сили, бачити часточку вкладеного тобою добра в іншій людині" [7: 413]. Таким чином, учитель-науковець пізнавав світ "не тільки розумом, а й серцем" [7: 414]. Якщо так, то виходить, що серце має пам’ять, а отже розум? У середині XX століття геній В. Сухомлинського осягнув те, про що стало відомо на початку XXI ст.

Якщо таким важливим є серце вчителя, його вплив на учня при передачі знань, почуттів, то як бути тоді 3 дистанційним навчанням, яке так настирно нав'язують? Як передати на відстані почуття, як поділитись енергією любові, теплом свого серця, інтелектом серця? Мабуть, на ці питання теж доведеться давати відповідь освітянам України у XXI столітті. Але шукати відповідь на ці питання повинні не тільки педагоги та психологи, але й науковці інших галузей знань на основі синергетичної моделі. За словами В. Кременя, "філософія освіти має залучити до свого дискурсу поняття, принципи, методи синергетики, які допоможуть звільнити свідомість від ідей і методів авторитарної педагогіки, від застосування засобів і способів прямого впливу на особистість. Використання синергетичного підходу в практичній діяльності сприяє збагаченню навчально-виховного процесу діалоговими засобами i методами освітньо-педагогічної взаємодії, що, у свою чергу, інтенсифікує розвиток як учнів, так i викладачів. У цьому - одне із завдань філософського підходу до процесів освіти взагалі" [10: 6].

Висновки та перспективи подальшого дослідження проблеми. Нашим дослідженням здійснено спробу довести українськість педагогічної спадщини В. Сухомлинського на ментальному, філософському, історичному, педагогічному, синергетичному рівнях. I завдання вчених, педагогівосвітян - у перспективі осмислити, як зробити так, щоб цей неоціненний доробок, цей неоціненний досвід вписався в освітній простір України майбутнього і став панівним. Для цього потрібні зусилля державного рівня. На часі - необхідність ввести Сухомлиністику як окрему навчальну дисципліну у кожному педагогічному університеті України, надати їй відцентрового змісту у підготовці вчителяпатріота, національно свідомого громадянина, інтелектуала XXI століття, українознавця планетарного мислення. Це особливо актуально у ситуації витискання свого, національного, із власної духовної території, що призводить до ослаблення національної ідентичності. Щоб протистояти космополітичній системі стандартів, уніфікацій, слід сформувати національну систему цінностей в освіті, забезпечену культурою традицій, патріотизмом, вірою в унікальність власного народу.

\section{СПИСОК ВИКОРИСТАНИХ ДЖЕРЕЛ ТА ЛІТЕРАТУРИ}

1. Клочек Г. Д. Константи Василя Сухомлинського : статті [Електронний ресурс] / Григорій Клочек. Кіровоград : РВВ КДПУ ім. В. Винниченка, 2008. - 67, [1] с. - Режим доступу: http://gazeta.dt.ua/SOCIETY/konstanti_vasilya_suhomlinskogo.html. - Назва з титул. екрану.

2. Жулинський М. Національні культури і проблеми глобалізації / М. Жулинський // Слово і час. - 2002. № 12. - С. 5-10.

3. Сухомлинський В. О. Серце віддаю дітям (нове прочитання) / Василь Сухомлинський ; передм. "У пошуках справжнього" О. Сухомлинської. - К. : Акта, 2012. - 537 с. 
4. Клизовский А. И. Основы миропонимания Новой Эпохи / А. И. Клизовский. - М. : ФАИР - ПРЕСС, 2003. $816 \mathrm{c}$.

5. Салас Д. С. Мораль ХХІ века : пер. с исп. / Дарио Салас Соммэр. - М. : ООО ИД "София", 2004. - 528 с.

6. Синергетика і освіта : [монографія] / за ред. В. Г. Кременя. - К. : Ін-т обдарованої дитини, - 2014. - 348 с.

7. Сухомлинський В. О. Вибрані твори : в 5 т. / В. О. Сухомлинський. - К. : Рад. школа, 1977. - Т. 5.

8. Клочек Г. Літературна класика як виклик / Г. Клочек // Дзеркало тижня. - 2008. - 6 вересня (№ 33). - С. 14.

9. Руденко М. Енергія прогресу : вибрані праці з економії, філософії і космології / М. Руденко ; упоряд. Р. А. Руденко. - К. : ТОВ "Вид-во "КЛІО"", 2015. - 680 с.

10. Кремень В. Синергетична модель розвитку освіти як відповідь на виклики сьогодення / В. Кремень // Рідна школа. - 2010. - № 6. - С. 3-6.

\section{REFERENCES (TRASLATED \& TRANSLITERATED)}

1. Klochek H. D. Konstanty Vasylia Sukhomlynskoho : statti [Vasyl Sukhomlynsky's Konstants] [Elektronnyi resurs] / Hryhorii Klochek. - Kirovohrad: RVV KDPU im. V. Vynnychenka, 2008. - 67, [1] c. - Rezhym dostupu : http://gazeta.dt.ua/SOCIETY/konstanti_vasilya_suhomlinskogo.html. - Nazva z tytul. ekranu.

2. Zhulynskyi M. Natsional'ni kultury i problem hlobalizatsii [National Cultures and Problems of Glabalization] / M. Zhulynskyi // Slovo i chas [Word and Time]. - 2002. - № 12. - S. 5-10.

3. Sukhomlynskyi V. O. Sertse viddaiu ditiam (nove prochytannia) [My Heart I Give to Children. New Reading] / Vasyl Sukhomlynskyi; peredm. "U poshukakh spravzhnoho" O. Sukhomlynskoi. - K. : Akta, 2012 . - 537 s.

4. Klyzovskyi A. I. Osnovu myroponymaniia novoi epokhi [Basics of Understanding of the New Era] / A. I. Klyzovskyi. - M. : FAYR - PRESS, 2003. - 816 s.

5. Salas D. S. Moral XIX veka : per. s isp. [Moral of the $21^{\text {st }}$ Century: Translated from Esp.] / Daryo Salas Sommer. M. : OOO "Sofiia", 2004. - 528 s.

6. Synerhetykai osvita : [monohrafiia] [Synergetics and Education] / za red. V. H. Kremenia. - K. : In-t obdarovanoi dytyny. -2014 . $-348 \mathrm{~s}$.

7. Sukhomlynskyi V. O. Vybrani tvory : v 5 t. [Selected Works: in Five Volumes] / V. O. Sukhomlynskyi. - K. : Rad. shkola, 1977. - T. 5. - 639 s.

8. Klochek H. Literaturna klasyka yak vyklyk [Literary Classics as a Challenge] / H. Klochek// Dzerkalo tyzhnia [Mirror of a Week]. - 2008. - 6 veresnia (№ 33). - S. 14.

9. Rudenko M. Enerhiia prohresu : vybrani pratsi z ekonomii, filosofii i kosmolohii [Energy of Progress: Selected Works on Economics, Philosophy and Cosmology] / M. Rudenko; uporiad. R. A. Rudenko. - K. : TOV "Vyd-vo "KLIO"", 2015. - $680 \mathrm{~s}$.

10. Kremen V. Synerhetychna model' rozvytku osvity yak vidpovidna vyklyky sohodennia [Synergetic Model of Education Development as a Response to the Challenges of the Nowadays] / V. Kremen // Ridnas hkola [Native School]. - 2010. - № 6. - S. 3-6.

\section{Циганок О. О., Санивский А. М. Философия для детей в педагогическом наследии В. Сухомлинского.}

В статье на основе комплексного анализа научно-педагогического наследия изучена суть философской системы В. Сухомлинского для детей. Педагогическое наследие изучалось на ментальном, философской, историческом, педагогическом, синергетическом ровнях. В результате соеланы выводы о необходимости введения Сухомлинистики как отдельной учебной дисциплины во всех педагогических университетах Украины, предоставляя ей основополагающее содержание в подготовке учителяпатриота, национально сознательного гражданина, интеллектуала ХХІ века, украинца планетарного мылиления.

Ключевые слова: В. Сухомлинский, философская система В. Сухомлинского для детей, педагогическая система В. Сухомлинского, формирование украинц̧а планетарного мышления.

\section{Tsyhanok O. O., Sanivskyi O. M. Philosophy for Children in the Pedagogical Heritage of V. Sukhomlynsky.}

The author of the article based on the complex analysis of scientific and pedagogical heritage found out the essence of $V$. Sukhomlynsky philosophical system for children. Pedagogical heritage was studied on the mental, philosophical, historical, pedagogical, and synergetic levels.

The scientists investigated Vasyl Oleksandrovych's pedagogical works through the present prism. Particularly relevant from this point of view are issues that affect the formation of a culture of needs of young Ukrainians, their moral, intellectual and physical development.

Also, the works of $V$. Sukhomlynsky are considered through the prism of the researches of V. Vernadskyi,

O. Klizovskyi, S. Krymskyi, B. Lypynskyi, M. Rudenko, G. Skovoroda, D. Sommer, D. Chyzhevskyi, in which the problem of formation of the new person of the $21^{\text {st }}$ century was developed.

The attention was drawn to the need of learning the resistant to cosmopolitan system of standards, unifications, depersonalization, the national system of values and priorities should be formed, and it should have cultural traditions, moral spirituality, conscious patriotism, faith in the uniqueness of own civilizational image and 
purpose. Such national system of educational values was presented in the pedagogical heritage of $V$. Sukhomlynsky, and it corresponds exactly to the demands of our time and our Ukrainian mentality. The authors concluded that Sukhomlynistyka as a separate discipline should be provided in every Ukrainian Pedagogical University. It should be giving centrifugal content in training of real teacher-patriot, nationally conscious citizen, intellectual of the $21^{\text {st }}$ century, Ukrainoznavtsa with global thinking. All that is especially actual in the situation of squeezing out our national from spiritual territory and that leads to the weakening of the national identity. The national system of values should be created in education for resistant of cosmopolitan system of standards and unifications. That system must have culture and traditions, patriotism, faith in the uniqueness of our people.

Key words: V. Sukhomlynsky, V. Sukhomlynsky's philosophical system for children, V. Sukhomlynsky's pedagogical system, formation of the Ukrainian with planetary thinking. 